\title{
Impact of Credit Demand on the Productivity of Rice Farmers in South West Nigeria
}

\author{
T.O. Ojo*1, L.J.S. Baiyegunhi² \& A.O. Salami ${ }^{3}$ \\ 1\&2SAEES (School of Agricultural, Earth and Environmental Sciences), University of KwaZulu-Natal, \\ Pietermaritzburg, South Africa \\ ${ }^{3}$ African Development Bank Headquarter Building Rue Joseph Anoma, Côte d'Ivoire \\ ojotemitope70@yahoo.com, baiyegunhil@ukzn.ac.za, A.SALAMI@afdb.org
}

\begin{abstract}
Employing cross-sectional data from 360 rice farmers selected from three states in South West Nigeria, the study analyzes the impact of credit demand on the productivity of rice farmers. An Endogenous Switching Regression Model (ESRM) that accounts for both heterogeneity and sample selection biases were used to estimate the impact of credit demand on rice productivity in South West Nigeria. In addition, a Tobit regression model was employed to measure the level of participation of rice farmers in the credit market. The result of the first stage (probit model) of the ESRM revealed that household assets, access to service, climate variables, regional variables, and transaction cost are statistically significant in influencing farmers' credit demand decision. The results of the second stage of the ESRM indicate factors such as household assets and access to service were statistically significant in explaining variations in rice productivity among participants and non-participants in the credit market. Furthermore, the results of the Tobit model showed that the farmers' location income from rice farming experience, interest rate, and distance to the source of credit are statistically significant determinants of the amount of credit received. These findings suggest that facilitating farmers' access to credit will improve rice productivity. Therefore, it is imperative for government and development partner to work together in order to improve the conditions for suitable agricultural credit access to rice farmers, especially a review of interest rates. A necessary addition should be developed to the assistance already being provided under Nigeria Incentive-Based Risk Sharing System for Agricultural Lending (NIRSAL) in the form of loan guarantees and other risk-sharing incentives, such as a regulatory environment that supports the modern contractual obligations that are characteristic of well-functioning agricultural financing. This would not only contribute to the intensification of rice production in Nigeria to meet its increasing rice demand, but also improve rice farmers' productivity and their households' incomes.
\end{abstract}

Keywords: Credit, Impact, Rice, Productivity, ESRM, Nigeria

\section{Background of the Study}

Many policy incentives have been put in place for Nigeria's financial system. This is in a bid to ensure that farmers have access to credit to finance their agricultural activities. Financial institutions such as microfinance banks, commercial banks, and Nigeria's Bank of Agriculture are being motivated to increase the credit supply to the agricultural sector one way of assessing how responsive the activities of the lending institutions have been to analyze credit market participation among farmers. Cultivation of most agricultural products-for example, paddy rice-involves a high cash outlay to meet operating costs during the cultivation season; hence, agricultural credit plays a significant role in increasing farm productivity (Iqbal, Munir \& Abbas 2003). The importance of credit in enabling smallholder farmers to master agricultural practices cannot be overemphasized (Siddiqi et al., 2004). Credit availability could enhance the adoption of technological advances in farming, resulting in increased productivity vis-a-vis increased revenue.

Credit plays an important role in increasing agricultural productivity at both the pre-planting and harvesting stages (Akpokodje, Lançon, \& Erensten, 2001); hence, timely access and availability of credit as posited by Saboor, Hussein, \& Munir (2009) are critical to farmers' acquisition of the inputs and machinery required to carry out farm activities. Credit is needed not only for farming purposes but also for household consumption, especially during the off-season. Under the Structural Adjustment Programme (SAP), the Nigerian Agricultural and Cooperative Bank (NACB) set up special credit schemes in 1988 to boost rice production. Under the schemes, the number of loans granted for rice production increased from 3,000 to 5,780 approved loans in 1989 (Akpokodje, Lançon, \& Erensten, 2001). The government has implemented policies such as the Nigeria Incentive-based Risk Sharing System for Agricultural Lending (NIRSAL) to ameliorate the situation, including a capital injection in 2009 to boost the financing of commercial agriculture. 
According to Guirkinger \& Boucher, (2008) and supported by Olomola \& Gyimah-Brempong (2014), the significant adverse effects of credit constraints on farm productivity of smallholder farmers in the rural areas of developing countries such as Nigeria is alarming. Farm productivity of staple crops, in developing nations such as Nigeria, is low due to traditional methods of farming, poor irrigation facilities, land fragmentation, the impact of climate change, misuse of modern agricultural technology, and less availability of credit (Chandio et al., 2017). Among all the staple crops, rice has risen to a position of eminence in Nigeria. Rice is the most important staple food for about half of the human race (Akinbode, 2013). According to USDA (2016), the annual consumption of rice in Nigeria was about 5 million MT while quantity supplied was 2.7 million MT, with a demand-supply gap of about 2.3 million MT which is today filled in by importation (Obih and Baiyegunhi, 2017). Nigeria still ranks third with Iraq (after the Philippines and China) in the group of major rice importing countries in the world (Awe, 2006). Among many factors that reduce the production of rice in Nigeria, credit constraints, credit market imperfections and stringent conditions for credit accessibility assumed to be strong contributors in making an investment in agriculture unattractive (Holden et al., 1998). It is therefore imperative to assess the impact of credit demand on the productivity of rice farmers in the study area.

The climate change and regional variables capture managerial and environmental differences among farms located in different States. While Alene \& Mayong (2007), focused on the effects of education on agricultural productivity in northern Nigeria, Baiyegunhi, Fraser, \& Darroch (2010) examined credit constraints and household welfare in the Eastern Cape Province of South Africa, and Awotide et al. (2015) investigated the impact of access to credit on the agricultural productivity of cassava in Nigeria. The current study contributes to the existing literature by extending the discussion to include climate change and regional variables. According to Rejitis et al. (2002), location variable is expected to have an impact on farmers' decisions to participate in the credit market, which encourages investment in the adoption of climate change adaptation strategies. Furthermore, the empirical technique advances the existing literature on the impact of credit demand on rice productivity by using a switching regression that segregates smallholder farmers in line with their participation in the credit market while simultaneously controlling for biases resulting from sample selectivity.

\section{Econometric Model}

Analyzing the impact of credit demand on rice productivity includes an examination of participation in the credit market and the factors (farmer's characteristics, farmers' assets and institutional factors) that influence the decision of rice farmers to borrow from the credit sources. In addition to the determinants of credit demand, such factors are crucial in understanding the functioning of the credit market and interpreting the prospects for rice farmers' relying on the market for farm financing. This implies that in addition to estimating the impact of credit demand on productivity, a choice model that describes whether a rice farmer decides to borrow is also estimated since the decision to borrow will affect the outcome of participation (rice yield) in the credit market. This study investigates the impact of smallholder farmers' demand for credit on rice productivity. Tiwasing et al. (2018) attempted to evaluate the effect of credit constraints and credit access, respectively, on outcomes by estimating separate production functions for those farmers that have access to credit and those that do not; the estimates were then compared. The major weakness of this particular method is the implicit assumption that all farmers that had access to credit and those that did not are respectively, the same in line with their credit demand situation.

Also, there is the problem of endogeneity, which arises from the assumption that demand for credit is voluntary. Thus, the major source of endogeneity is self-selection into demand for credit. To address this, an approach that explicitly accounts for such endogeneity simultaneously should be used as posited by Hausman (1983). Therefore, this study precisely corrects for any possible sample selection bias that may arise from other interventions that provide multiple services to farmers in addition to credit with the aid of an endogenous switching regression model (Lee, 1978 and Maddala, 1983). Following Lokshin \& Sajaia (2004), Nyangena \& Köhlin (2008), Asfaw, Mithöfer, \& Waibel (2010), and Aravindakshan et al. (2018), this study estimated a endogenous switching regression (ESR) model (Maddala \& Nelson 1975; Maddala 1983) to deal with the problems presented by both sample selection bias and endogeneity (Heckman 1979; Hausman 1978), allowing for interactions between credit market participation and other covariates (Alene \& Manyong 2007). 


\section{Journal of Economics and Behavioral Studies (ISSN: 2220-6140)}

Vol. 11, No. 1, pp. 166-180, February 2019

This model is divided into two parts: the first correct for endogeneity due to self-selection using a probit selection model in which farmers are sorted into participants and non-participants, while the second part of the model addresses the outcome equations on factors influencing productivity.

$$
\begin{gathered}
Y_{i}^{*}=\beta Z_{i}+\varepsilon_{i} \\
Y_{i}=1 \text { if } Y_{i}^{*}>0 \\
Y_{i}=0 \text { If } Y_{i}^{*} \leq 0,
\end{gathered}
$$

Where $\mathrm{Y}^{*}$ is the unobservable (or latent) variable for credit market participation; $\mathrm{Y}$ is the observable counterpart (equal to one if the farmer participated in the credit market and zero otherwise) and $\varepsilon$ represents the random disturbances associated with credit participation. In the second stage, the outcome equation on the impact of credit market participation rice farmers' productivities is estimated through a production function, expressed in equation (2) as:

$$
Q=f(Y, \beta, Z)+\varepsilon
$$

Where $Q$ is the $\log$ form of rice yield; $Y$ refers to credit market participation; $\beta$ is a vector of parameters to be estimated; and $Z$ is a set of explanatory variables used in the model.

Regime 1 (participants): $\quad Q_{1 i}=\lambda_{1} H_{i}+v_{1 i}$

Regime 2 (non-participants): $Q_{2 i}=\lambda_{2} H_{i}+v_{2 i}$,

Where $Q_{1 i}$ and $Q_{2 i}$ are the logs of rice yield productivities of the farmers in regimes 1 and 2, respectively. $H_{i}$ Represent a vector of exogenous variables that are hypothetically assumed to determine the rice productivity function. $v_{1 i}$ and $v_{2 i}$ are the error terms. Finally, the error terms are believed to have a trivariate normal distribution, with zero mean and non-singular covariance matrix expressed as follows:

$$
\operatorname{cov}\left(\varepsilon_{i} v_{1} v_{2}\right)\left|\begin{array}{lll}
\sigma_{1}^{2} & \sigma_{12} & \sigma_{1 \varepsilon} \\
\sigma_{12} & \sigma_{2}^{2} & \sigma_{2 \varepsilon} \\
\sigma_{1 \varepsilon} & \sigma_{2 \varepsilon} & \sigma^{2}
\end{array}\right|
$$

Where

$\sigma_{1}^{2}=\operatorname{var}\left(v_{1}\right) ; \sigma_{2}^{2}=\operatorname{var}\left(v_{2}\right) ; \sigma^{2}=\operatorname{var}\left(\varepsilon_{1}\right) ; \sigma_{12}=\operatorname{cov}\left(v_{1} v_{2}\right) ; \sigma_{1 \varepsilon}=\operatorname{cov}\left(v_{1}, \varepsilon i\right) ; \sigma_{2 \varepsilon}=\operatorname{cov}\left(v_{2,} \varepsilon_{i}\right) ; \sigma^{2}$

Represent variance of the error term in the selection equation and $\sigma_{1}^{2}, \sigma_{2}^{2}$ represent variance of the error term in the in the outcome equation.

Following Maddala (1983), the existence of latent characteristics related to selection bias indicates that, the error structure is based on the account that the error term $\left(\varepsilon_{i}\right)$ of the selection equation (2) is correlated with the error terms $\left(v_{1 i}\right.$ and $v_{2 i}$ ) of the outcome equations $3 \mathrm{a}$ and $3 \mathrm{~b}$, the expected values of $v_{1 i}, v_{2 i}$ conditional on the sample selection are non-zero.

$$
\begin{aligned}
& E\left(v_{1 i} \mid Y_{i}=1\right)=E\left(v_{1 i} \mid \varepsilon_{i}>-Z_{i} \beta\right)=\sigma_{1 \varepsilon}\left[\frac{\theta\left(Z_{i} \beta / \sigma\right.}{\varphi\left(Z_{i} \beta / \sigma\right.}\right] \equiv \beta_{1 \varepsilon} \gamma_{1} \\
& E\left(v_{2 i} \mid Y_{i}=0\right)=E\left(v_{2 i} \mid \varepsilon_{i} \leq-Z_{i} \beta\right)=\sigma_{2 \varepsilon}\left[\frac{-\theta\left(Z_{i} \beta / \sigma\right.}{1-\varphi\left(Z_{i} \beta / \sigma\right.}\right] \equiv \beta_{2 \varepsilon} \gamma_{2},
\end{aligned}
$$

Where $\theta$ and $\varphi$ are the probability density and cumulative distribution functions of the standard normal distribution, respectively. The ratio of $\theta$ and $\varphi$ evaluated at $\beta Z_{i}$, represented by $\gamma_{1}$ and $\gamma_{2}$ in equations 5 a and $5 \mathrm{~b}$ is referred to as the inverse mills ratios (IMRs), which indicate selection bias terms. The IMR shows the 
correlation between credit participation and rice productivity. Previous studies have used a two-stage method to estimate the endogenous switching model (Lee, 1978; Feder et al., 1989; Fuglie \& Bosch 1995; Freeman et al., 1998). In the first stage, a probit model of the criterion equation is estimated and the IMRs $\gamma_{1}$ and $\gamma_{2}$ are derived according to definitions in equations $5 \mathrm{a}$ and $5 \mathrm{~b}$. In the second stage, these predicted variables are added to the appropriate equation in $3 \mathrm{a}$ and $3 \mathrm{~b}$, respectively, to yield the following sets of equations"

$$
\begin{aligned}
& Q_{1 i}=\lambda_{1} H_{i}+\beta_{1 \varepsilon} \gamma_{1}+\phi_{i} Y_{1 i}+\psi_{1} \\
& Q_{2 i}=\lambda_{2} H_{i}+\beta_{2 \varepsilon} \gamma_{2}+\phi_{2 i} Y_{2 i}+\psi_{2}
\end{aligned}
$$

The coefficients of the variables $\gamma_{1}$ and $\gamma_{2}$ provide estimates of the covariance terms $\beta_{1 \varepsilon}$ and $\beta_{2 \varepsilon}$, respectively. Since the variables $\gamma_{1}$ and $\gamma_{2}$ have been estimated, the residuals $\psi_{1}$ and $\psi_{2}$ cannot be used to calculate the standard errors of the two-stage estimates. In the literature, a two-step ESR procedure involving estimation of the probit selection Perloff et al. (1998) employ model and outcome equation. Heteroskedastic errors are always confounded with the method of inserting IMRs from probit equations manually into outcome equations. According to Lokshin \& Sajaia (2004), Full Information Maximum Likelihood (FIML) is an efficient method to analyze the ESRM. Estimators obtained by FIML enjoy all the properties of maximum likelihood estimators. They are consistent and asymptotically normally distributed. The FIML simultaneously fits the selection (equation 1 ) and outcome ( $3 \mathrm{a}$ and $3 \mathrm{~b}$ ) equations in order to yield consistent standard errors, thus making $\gamma_{1}$ and $\gamma_{2}$ in equation $6 \mathrm{a}$ and $6 \mathrm{~b}$, respectively homoscedastic.

The FIML's log-likelihood function for the switching regression model employed in this study as proposed by Lokshin and Sajaia (2004) is described below:

$$
\left.\operatorname{Ln} Y_{i}=\sum_{i=1}^{N} \| \begin{array}{l}
Y_{i} t_{i}\left[\ln F\left(\frac{\left.Z_{i} \beta+\sigma_{1 \varepsilon}\left(Q_{1 i}-H_{1 i} \lambda / \phi_{1}\right)\right)}{\sqrt{1-\alpha_{1 i}^{2}}}\right)+\ln \left(f\left(Q_{1 i}-H_{1 i} \lambda / \phi_{1}\right]+\right.\right. \\
\left(1-Y_{1}\right) t_{i}\left[\frac{\ln \left(1-F\left(Z_{i} \beta+\sigma_{2 \varepsilon}\left(Q_{2 i}-H_{2 i} \lambda / \phi_{2}\right)\right)\right.}{\sqrt{1-\alpha_{2 \varepsilon}^{2}}}\right)+\ln \left(f \left(Q_{2 i}-H_{2 i} \lambda / \phi_{2}\right.\right.
\end{array}\right] \|
$$

According to Fuglie and Bosch (1995), the signs of the correlation coefficients $\alpha_{i \varepsilon}$ and $\alpha_{2 \varepsilon}$ have economic meanings. If $\alpha_{i \varepsilon}$ and $\alpha_{2 \varepsilon}$ have alternate signs, rice farmers participated in the credit market based on their comparative advantage: those farmers that participate in the credit market have above-average productivity and non-participants have above-average productivity. However, if the coefficients have the same sign, that indicates hierarchical sorting: participants have above-average productivity whether they participate or not, but they are better off if they participate, whereas the non-participants have below-average productivity in either case, but they are better off not participating. Following Awotide et al. (2016), and Danso-Abbeam \& Baiyegunhi (2017), this study employed the Tobit regression model to determine the level of participation of rice farmers in the credit market. The level of participation is measured as the amount of credit received from the credit market. Following the literature on the determinants of access to credit, the following explanatory variables were included in the Tobit model age and gender of the head of household, farm size, marital status, household size, years of formal education.

Income from off-farm activities, contacts with extension agent, membership in a cooperative society, farming experience access to climate change information, climate variables, regional variables, and transaction costs for credit. The Tobit regression model developed by Tobin, (1958) is a hybrid of discrete and continuous dependent variables that express the relationship between a nonnegative exogenous dependent variable (Y) and a vector of explanatory variables (X). The Tobit model is relevant in this study because of its ability to avoid the censoring biases that the Ordinary Least Square (OLS) estimator could present. It is obvious from the data collected that some groups of farmers did not participate in the credit market and, hence, the amount received 
by this group is censored at zero. Thus, the Tobit model censored the decisions of farmers to participate in the credit market at zero. The model supposes that there is a latent unobservable variable $Y_{i}^{*}$ that determines the value of the observable variable $Y_{i}$ (amount received) this unobservable variable $Y_{i}^{*}$ linearly depends on $X_{i}$ (age and gender of the household head, farm size, marital status, household size, years of formal education, income from off-farm activities. Contacts with extension agent, membership in a cooperative society, farming experience, access to climate change information, climate variables, regional variables, and transaction costs for credit), via a parameter (vector) $\beta^{\prime}$, which determines the relationship between the independent variable (or vector) $X_{i}$ and the latent variable $Y_{i}^{*}$ (just as in a linear model). In addition, there is a normally distributed error term $u_{i}$ to capture random influences on this relationship the observable variable $Y_{i}$ is defined to be equal to the latent variable $Y_{i}^{*}$ whenever the latent variable is above zero and zero otherwise. Since the threshold for the amount received is zero (cannot be negative), the dependent latent variable can be specified as an index function (Maddala 1983).

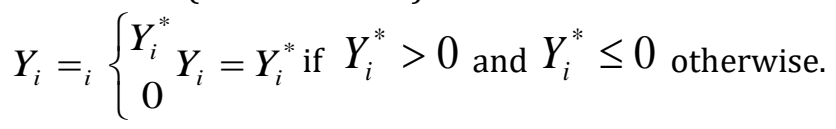

It is assumed that $Y_{i}^{*}$ can be specified as follows:

$$
Y_{i}^{*}=\beta^{\prime} X_{i}+\mu_{i} \mu_{i} \approx N\left(0, \sigma^{2}\right),
$$

Where $Y_{i}^{*}$ is the latent variable of the amount of credit received and the vector of independent variables is denoted by $X_{i} . \beta^{\prime}$ is the vector of unknown coefficients and $\mu_{i}$ is an independently distributed error term.

If the relationship parameter $\beta$ is estimated by regressing the observed $Y_{i}$ on $X_{i}$, the resulting ordinary least square regression estimates will be inconsistent, as they will yield a downward-biased estimate of the slope coefficient and an upward-biased estimate of the intercept. According to Amemiya (1973), the maximum likelihood estimator suggested by Tobin for this model is consistent.

$$
\begin{aligned}
& V=\bigcap_{0} \Psi_{i}\left(Y_{0}\right) \bigcap_{1} \Phi_{1}\left(Y_{i}\right) \\
& V=\bigcap_{0}\left[1-\Psi_{i}\left(X_{i} \beta / \sigma\right)\right] \bigcap_{1} \sigma^{-1} \Phi_{1}\left[\left(Y_{i}-X_{i} \beta\right) / \sigma\right],
\end{aligned}
$$

Where $\Psi$ and $\Phi$ are the standard normal density and cumulative distribution functions, respectively. Then the log-likelihood function can be written as

$$
L n V=\sum_{0} \ln \left(1-\Psi\left(X_{i} \beta / \sigma\right)+\sum_{1} \ln \left(\frac{1}{\left.2 \bigcap \sigma^{2}\right)^{1 / 2}}\right)-\sum_{1} \frac{1}{2 \sigma^{2}}\left(Y_{i}-\beta X_{i}\right)^{2}\right.
$$

The parameters $\beta$ and $\sigma$ are estimated by maximizing the log-likelihood function:

$$
\begin{aligned}
& \frac{\partial \operatorname{Ln} V}{\partial \beta}=\sum_{0} \frac{X_{i} \Phi\left(X_{i} \beta\right) / \sigma}{1-\Psi\left(X_{i} \beta / \sigma\right)}+\frac{1}{\sigma^{2}} \sum_{1}\left(Y_{i}-\beta X_{i}\right)=0 \\
& \frac{\partial \operatorname{Ln} V}{\partial \sigma^{2}}=\frac{1}{2 \sigma^{2}} \sum_{0} \frac{\beta X_{i} \Phi\left(X_{i} \beta / \sigma\right)}{1-\Psi\left(X_{i} \beta / \sigma\right)}-\frac{n_{i}}{2 \sigma^{2}}+\frac{1}{2 \sigma^{4}} \sum_{1}\left(Y_{i}-\beta X_{i}\right)^{2}=0
\end{aligned}
$$

Since the two equations (12) are non-linear the maximum likelihood estimator must be obtained by an iterative process (Greene 2003). 


\section{Study Area and Method of Data Collection}

The study was carried out in the southwestern part of Nigeria. Southwestern Nigeria consists of Lagos, Ogun, Oyo, Osun, Ondo and Ekiti States, collectively known as the South-West geographical zone of Nigeria. The area lies between longitudes $2^{0} 31^{1}$ and $6^{0} 00^{1}$ East and latitudes $6^{0} 21^{1}$ and $8^{0} 37^{1} \mathrm{~N}$, with a total land area of about $77,818 \mathrm{~km}^{2}$. It is bounded in the east by Edo and Delta State in the north by Kwara and Kogi States, in the west by the Republic of Benin and in the south by the Gulf of Guinea. The climate of Southwest Nigeria is tropical in nature and is characterized by wet and dry seasons. The mean temperature ranges between $21^{\circ} \mathrm{C}$ and $34^{\circ} \mathrm{C}$, while the annual rainfall ranges between $150 \mathrm{~mm}$ and $3000 \mathrm{~mm}$. The wet season is associated with the southwest monsoon wind from the Atlantic Ocean while the dry season is associated with the northeast trade wind from the Sahara desert. A multistage sampling technique was used for the selection of the respondents.

The first stage involved a purposive selection of three states-Ekiti, Ondo, and Osun-and the second stage with the same technique was used to select local government areas) from each state based on the predominant smallholder rice farmers in these areas. The third stage involved a random selection of 5 villages each from the four LGAs selected in the second stage. The last stage involved a random selection of 6 smallholder rice farmers in each of the villages to arrive at a total of 360 respondents used for the study. Following Tesfahunegn et al. (2016), at 95\% confidence level and 5\% margin of error, the sample size of for the study was determined using the sample determination formula as described by Cochran (1977). Based on the total household heads and sample size, the interval size was determined by dividing the total household heads by the sample size. A respondent was then selected within the interval using simple random sampling.

Data were collected using a pre-tested, well-structured questionnaire on socio-economic characteristics of the respondents, adaptation to climate change strategies, determinants of adaptation strategies, and the costs and returns to rice production. In addition, the study also conducted focus group discussions to engender information on the farmers' knowledge about climate change and its related hazards, susceptible groups in the area and existing adaptation strategies. Twelve focus group discussions were conducted in each of the local government areas with the participation of at least 10 farmers from each area. Information sought included climate change-related hazard and adaptation strategies employed to mitigate its effects. Information from the focus group discussions helped in the restructuring of the questionnaire. In line with the climate variables, monthly averages for precipitation and temperature from 1970 to 2014 were obtained from the Nigeria Meteorological Agency (NIMA) at Oshodi in Lagos, Nigeria and the International Institute for Tropical Agriculture (IITA) in Ibadan, Nigeria.

\section{Results and Discussion}

A brief definition and summary statistics of some variables used in the model are presented in Table 1.

Table 1: Definitions and Summary Statistics of Variables Used in the Model

\begin{tabular}{llll}
\hline Variables & Description of variables & Mean & SD \\
\hline $\begin{array}{l}\text { Dependent } \\
\text { Rice yield }\end{array}$ & Log of output of rice kg/ha & \\
Access to credit & Dummy = 1 if HH had access to credit; 0 otherwise & 0.57 & 0.50 \\
Independent & & & \\
& & 0.56 & 0.50 \\
Gender & Dummy =1 If household head is male; 0 otherwise & 47.28 & 7.67 \\
Age of the head of household & Age of head of household (years) & 0.80 & 0.40 \\
Marital status & 1 if head of household is married; 0 if single or widowed & 6.45 & 5.70 \\
Educational status & Years of education of the head of household & 4.66 & 1.24 \\
Household size & Number of people in the household & 0.54 & 0.50 \\
Off-farm income & 1 if household engages in any off-farm activity & 15.73 & 5.09 \\
Farming exp & Years of household experience in rice production &
\end{tabular}




\begin{tabular}{llll}
\multicolumn{4}{c}{$\begin{array}{c}\text { Journal of Economics and Behavioral Studies (ISSN: 2220-6140) } \\
\text { Vol. 11, No. 1, pp. 166-180, February 2019 }\end{array}$} \\
\hline \hline Farm size & Total land owned by the household in hectares & 7.37 & 3.04 \\
Acc to climate info & 1 if household had climate change information; 0 otherwise & 0.36 & 0.48 \\
Acc to ext contacts & 1 if household had access to extension; 0 otherwise & 0.53 & 0.50 \\
Membership & 1 if household belongs to Farmers' Association & 0.54 & 0.50 \\
Mean annual tempt & Mean of annual temperature $\left({ }^{\circ} \mathrm{C}\right)$ & 27.66 & 0.05 \\
& & 111.0 & 16.0 \\
Mean annual Ppt & Mean of annual precipitation $(\mathrm{mm})$ & 5 & 9 \\
Location_Ekiti State & 1 if household is from Ekiti; 0 otherwise & 0.38 & 0.48 \\
Location_Ondo State & 1 if household is from Ondo; 0 otherwise & 0.38 & 0.49 \\
Location_Osun State & 1 if household is from Osun; 0 otherwise & 0.35 & 0.48 \\
\hline
\end{tabular}

The results in Table 1 show that household heads' average age and years of education are 47 and six years, respectively. On extension access, about $53 \%$ of the respondents have contact with extension agents. Access to credit is a major determinant in choosing adaptation strategies, but only about $57 \%$ of the smallholder rice farmers have access to credit. However, there are clear variations in terms of access to information for example about $36 \%$ of the farmers who at least adopted a strategy has access to information related to climate change. About $47 \%$ of the smallholder rice farmers in the study area are risk-constrained, while $37 \%$ of them are priceconstrained and 57\% are quantity-constrained. The average farming experience of the farmers in the study area is 15 years. The result is in agreement with Hitayezu, Okello \& Gor (2010), who posited that farmers' perception and efficient response to the economic conditions is directly related to their resource allocation ability, which is subsequently linked to their human capital endowment.

Determinants of Credit Market Participation: FIML Estimates of the ESRM: This section presents the empirical evaluation of the impact assessment. The correlation coefficients rho_1 and rho_2 of the ESRM are both negative and are statistically significant for both the correlation between the credits market participation equation and the yield of the participants and non-participants in the credit market. This shows that the participants have above-average productivity regardless of whether they participate in the credit market or not, but they are better off if they have access to credit, whereas non-participants have below-average productivity in either case but they are better off as non-participants. The statistical significance of likelihood ratio test at $1 \%$ for joint independence of the three equations implies that they should not be estimated separately. The result of the ESRM estimation is in three parts, as presented in Table 2, the first part of the probit model of the determinants of demand for credit.

Table 2: FIML Estimates of the Endogenous Switching Regression Model

\begin{tabular}{|c|c|c|c|c|c|c|}
\hline & \multicolumn{2}{|c|}{ Demand for credit } & \multicolumn{2}{|c|}{ Participants } & \multicolumn{2}{|c|}{ Non-participants } \\
\hline & Coef. & Std. Err. & Coef. & Std. Err. & Coef. & Std. Err. \\
\hline \multicolumn{7}{|l|}{ Lnoutput/ha } \\
\hline Gender & 0.1980 & 0.221 & 0.005 & 0.011 & 0.005 & 0.011 \\
\hline Age & $0.032^{c}$ & 0.017 & -0.001 & 0.001 & 0.000 & 0.001 \\
\hline Marital status & $-1.322^{a}$ & 0.34 & $-0.085^{c}$ & 0.014 & $-0.093^{a}$ & 0.015 \\
\hline Educational status & $0.059^{b}$ & 0.025 & $-0.009^{a}$ & 0.001 & $-0.008^{a}$ & 0.001 \\
\hline Farming experience & $0.047^{c}$ & 0.025 & $-0.003 a$ & 0.001 & -0.001 & 0.001 \\
\hline Household size & 0.029 & 0.079 & $0.011^{a}$ & 0.004 & -0.006 & 0.004 \\
\hline Farm size & $-0.072^{c}$ & 0.042 & $0.005^{a}$ & 0.002 & 0.001 & 0.002 \\
\hline Off farm income & 1.078 & 0.988 & -0.054 & 0.039 & -0.005 & 0.044 \\
\hline Acc. to extension & $-1.780^{b}$ & 0.896 & 0.051 & 0.039 & 0.010 & 0.044 \\
\hline Climate Info Acc. & $0.800^{a}$ & 0.267 & -0.008 & 0.014 & $-0.061^{a}$ & 0.018 \\
\hline Location_Ekiti & $-0.569 b$ & 0.26 & 0.018 & 0.015 & -0.015 & 0.013 \\
\hline
\end{tabular}




\begin{tabular}{|c|c|c|c|c|c|c|}
\hline \multicolumn{7}{|c|}{$\begin{array}{l}\text { Journal of Economics and Behavioral Studies (ISSN: 2220-6140) } \\
\text { Vol. 11, No. 1, pp. 166-180, February } 2019 \\
\end{array}$} \\
\hline Location_Ondo & $0.432^{c}$ & 0.247 & -0.008 & 0.015 & -0.002 & 0.013 \\
\hline Location_Osun & $-0.913^{b}$ & 0.364 & -0.023 & 0.016 & -0.019 & 0.016 \\
\hline Annual temp & $-5.607^{b}$ & 2.452 & 0.025 & 0.114 & 0.016 & 0.118 \\
\hline Annual ppt & $-0.050^{a}$ & 0.016 & 0.000 & 0.001 & 0.000 & 0.001 \\
\hline Constant & 158.104 & 68.236 & 6.903 & 3.176 & 7.142 & 3.286 \\
\hline Distance to source & $0.040^{b}$ & 0.018 & & & & \\
\hline Sources & $-1.773^{a}$ & 0.452 & & & & \\
\hline Membership & 0.937 & 1.007 & & & & \\
\hline /lns1 & $-2.700^{a}$ & 0.071 & & & & \\
\hline /lns2 & $-2.588^{a}$ & 0.051 & & & & \\
\hline$/ \mathrm{r} 1$ & $-1.047^{a}$ & 0.433 & & & & \\
\hline$/ \mathrm{r} 2$ & $-1.138 a$ & 0.335 & & & & \\
\hline sigma_1 & $0.067^{a}$ & 0.005 & & & & \\
\hline sigma_2 & $0.075^{a}$ & 0.004 & & & & \\
\hline rho_1 & $-0.781^{a}$ & 0.169 & & & & \\
\hline rho_2 & $-0.814^{a}$ & 0.113 & & & & \\
\hline
\end{tabular}

Note: $a, b$, and c represent significance level at $1 \%, 5 \%$, and $10 \%$, respectively.

Fourteen of the eighteen variables included in the probit model are statistically significant in influencing the choice of credit demand. The results of the probit model revealed that farmers' socio-economic characteristic variables such as the age of the household head, marital status, and educational level are statistically significant. Furthermore, household asset variables, farming experience, and farm size are also statistically significant in influencing the decision to participate in the credit market. Others variable that is significant is access to service, climate variables, regional variables, and transaction costs. As presented in Table 2, the estimates of the second-stage switching regression model for rice productivity (output per hectare) are indicated as participants and non-participants. The coefficients of marital status, educational status, and farming experience are negative and are statistically significant in influencing rice productivity among the farmers that participated in the credit market. In the same vein, the coefficients of marital status, educational status, and access to climate change information are negative and statistically significant in influencing rice productivity among nonparticipants. The results imply that a unit increase in rice farmers' marital status, number of years spent in school, and access to climate change information will cause a $9.3 \%, 0.8 \%$, and $6.1 \%$ respective reduction in the productivity of rice.

A plausible explanation for the negative relationship between the farming experience and rice productivity could be attributed to the conventional nature of some experienced farmers. Some farmers are so satisfied with their rudimentary method of farming such that they find it difficult to switch to new farming practices, hence, reduce productive efficiency. This finding is in consonance with Danso-Abbeam \& Baiyegunhi, (2017) who also found a negative relationship between farming experience and technical efficiency among cocoa farmers in Brong-Ahafo region of Ghana. The number of years spent in school is negatively signed with rice productivity could also be traced to the fact that the number of years in formal education may not necessarily increase one's productive efficiency as compared with the level of knowledge in its production environment. The finding is in line with the studies of (Binam et al. 2008; Onumah et al. 2013) who also estimated education as a decreasing function of productivity. The coefficients of farm size and household size are both positive and statistically significant in explaining variations in the productivity of rice. This is in consonance with both the Rahman (2009) and Benin et al. (2004) studies that showed that crop productivity is positively influenced by farm size. These findings also corroborate the results of Tijani, Alimi, \& Adesiyan (2006) and Abdallah (2016), which found a positive relationship between farm size and crop yield. It is thus expected that rice productivity improves significantly when rice farmers have enough land for production. 
Family size significantly influences rice production. Benin et al. (2004) noted the significantly positive influence of male members in the family on cereal crop diversity on farms in Ethiopia. The results from Table 2 show that an increase in both farm size and family size will increase rice productivity by $0.5 \%$ and $1.1 \%$, respectively. The results of this study show that the coefficient of household size has a positive relationship with rice productivity. This indicates that household size has a positive influence on the output of rice farmers in the study area. The implication is that members of the household contribute significantly to the supply of family labour, which leads to an increase in rice yield (Danso-Abbeam \& Baiyegunhi, 2017). This is in consonance with the result of the findings of Okorie et al. (2011), who noted that farmers with increased household size obtained higher yield due to family labour supply. This reduces the production cost since the cost of family labour is not always incorporated in the cost of production cost, especially in developing countries.

\section{Determinants of Rice Farmers' Credit Market Participation}

Household Characteristics: Among farmers' household characteristic variables that were included in the probit model, the age of the household head, marital status, and educational level are statistically significant in influencing the decision to participate in the credit market. The coefficient of the age of the household head was found to be positive and statistically significant in influencing the decision to participate in the credit market. That means that with an increase in age, the probability of participating in the credit market increases. This implies that older farmers were more likely to participate in the credit market, which is traceable to farming experience because older farmers are well aware farm management operations (Enete \& Igbokwe 2009; Shalmani et al., 2017). The coefficient of the level of education is positive and statistically significant in influencing the decision to participate in the credit market. A probable implication is that educated households are more aware of credit opportunities and the procedures required credit accessibility.

The result of this study is consistent with the findings in the literature (Kumar et al. 2013; Pal \& Laha 2015). It also in line with the assertions of Amjad \& Hasnu (2007), who reported a positive influence of educational level on households' ability to cope with the stringent procedures required for credit access. Education plays a major role in borrowing decisions and reduces credit transaction costs. Conversely, the coefficient of marital status is negative and statistically significant in influencing the choice of participating in the credit market. This indicates that single-headed household farmers are more likely to participate in the credit market than their married counterparts. This is contrary to the findings of Nnadi \& Akwiwu (2008) who noted that being married enhances farmers' concerns for their household's welfare and food security and therefore is likely to have a positive effect on their decision to participate in an agricultural credit market.

Household Assets: Unexpectedly, the coefficient of farm size is negative and statistically significant. This implies that with an increase in farm size, the probability of participating in the credit market decreases. This result is consistent with the findings of Sebopetji \& Belete (2009) that there is a negative relationship between farm size and credit access. However, the coefficient of years of experience in rice farming is positive and statistically significant in influencing the decision to participate in the credit market. This implies that years of farming experience significantly increases the probability of participating in the credit market. As opined by Mishra et al. (2002), farming experience helps in making a better decision- in line with farm financing. Results from this study are in consonance with the findings of Sebopetji \& Belete (2009) and Nouman et al. (2013), all of which report a positive relationship between access to agricultural credit and farming experience. As supported by Yehuala (2008), farmers with more farming experience are better positioned with cooperatives and other formal lending institutions.

Access to Services: The coefficient of access to extension service is negative and statistically significant in influencing farmers' decisions to participate in the credit market contrary to the a priori expectation. This implies that an increase in contacts with extension agents reduces the probability of participating in the credit market. This could be attributed to inadequate or unqualified staff members and poor organization, which could limit the efficient dissemination of agricultural extension services (De, Uchiyama, \& Ohara, 2005). As a result, credit information might not be disseminated efficiently through extension systems. An individual exposed to climate change information is more likely to take immediate action to cope with risks related to climate change. The coefficient of access to climate information is positive and statistically significant with the decision to participate in the credit market. This implies that the higher the access to climate change 
information, the higher the likelihood of participating in the credit market. Farmers' access to credit can mitigate the effects of these climate change shocks. This argument is in line with the findings of Diagne et al. (2000) and Luan \& Bauer (2016), both of which identify credit as the major instrument of improving climate changes adaptation strategies for farmers.

Transaction Costs: A negative relationship is expected between credit demand and interest rates, but the result of the analysis shows a positive relationship. The coefficient of the interest rate is positive and statistically significant in influencing the participation of rice farmers in the credit market. This result implies that the likelihood of rice farmers participating in the credit market increases as the interest rate increases. This result is in line with Olomola \& Gyimah-Brempong (2014), which finds a positive relationship between credit rationing and interest rate in loan demand and rationing among small-scale farmers in Nigeria. In the same vein, the coefficient of distance to the credit source is also positive and statistically significant in influencing the decision to participate in the credit market. As indicated by Balogun \& Yusuf (2011), the result implies that regardless of distance or interest rate, smallholder farmers will have demand credit because of their urgent need and limited supply. This is also corroborated by the findings of Karlan \& Zinman (2008), who postulate that credit is more critical than interest rates in the case of developing nations. This current study finds that when credit activities are carried out in a motivated manner, availability is of greater importance than the related transaction costs.

Location: The coefficient of location of Ondo State exhibited a positive and significant relationship with participation in the credit market. This shows that locational differences exist in the access of smallholder farmers to agricultural credit, with rice farmers in Ondo State being more likely to be involved in credit market participation than those in both Osun and Ekiti State. Their coefficient is negative but statistically significant in influencing the decision to participate in the credit market. Locational discrepancies in the dispensation of lending institutions as well as other latent locational discrepancies could account for the differences in access to credit (Olomola \& Gyimah-Brempong 2014). This could be attributed to the existence of the Ondo State long before the other two locations, which has allowed farmers in Ondo State to benefit more from credit information through Agricultural Development Program system (Afolami et al., 2012).

Climate Variables: The coefficient of mean annual temperature is negative and statistically significant in influencing the rice farmers' participation in the credit market. This implies that the probability of participating in credit falls with a decrease in temperature. This could be attributed to the fact that a decrease in annual temperature may require low investment in the use of adaptation strategies to the impact of climate change. Furthermore, the coefficient of mean annual precipitation is also negative and statistically significant in influencing participation in the credit market. This implies that the probability of participating in the credit market is low. This is rather an unexpected result as farmers respond to drought by investing in adaptation strategies to climate change. Empirical findings have indicated access to credit as a major determinant of climate changes adaptation strategies (Kandlikar \& Risbey 2000). Recent studies (Gyinadu, Bakang, \& Osei, 2015; Mmbando \& Baiyegunhi 2016) also found that insufficient funds or a lack of funds have restrained adoption of farm management practices in developing nations.

Estimation Result of the Tobit Model for Amount of Credit Obtained: The estimated results from the Tobit model explain the level of participation in the credit market. As asserted by McDonald \& Moffit (1980), the coefficients of Tobit regression are interpreted in a similar way to OLS regression coefficients; nevertheless, the linear effect is on the uncensored latent variable, not the observed outcome. The result of the Tobit model presented in Table 3 shows that 5 out of 17 variables included in the model are statistically significant with the amount of credit received. The estimated coefficient of revenue from rice production is negative and statistically significant in influencing the amount of credit obtained. This implies that revenue from rice production in the study area has a negative effect on the amount of credit obtained by farmers. The result shows that for a unit increase in rice revenue, there is a $72 \%$ decrease for credit obtained by the farmers. The result is corroborated by the findings of Diagne \& Zeller (2001) that there is a negative relationship between borrowing and the net farm income of households in Malawi. This could be attributed to the fact that farmers with higher income can self-finance their farming activities and therefore were not in need of agricultural credit (Nouman et al., 2013). 
Journal of Economics and Behavioral Studies (ISSN: 2220-6140)

Vol. 11, No. 1, pp. 166-180, February 2019

Table 3: Estimation Result of the Tobit Model of Amount of Credit Obtained

\begin{tabular}{|c|c|c|c|}
\hline Lnamount & Coef. & Std. Err. & P-value \\
\hline Location_Ekiti & -0.501 & 0.396 & 0.207 \\
\hline Location_Ondo & 0.199 & 0.378 & 0.598 \\
\hline Location_Osun & -1.113 & 0.412 & $0.007^{a}$ \\
\hline Gender & 0.407 & 0.363 & 0.264 \\
\hline Age & 0.022 & 0.024 & 0.364 \\
\hline Educational status & -0.055 & 0.039 & 0.163 \\
\hline Marital status & -0.594 & 0.614 & 0.334 \\
\hline Off-farm income & -0.156 & 1.655 & 0.925 \\
\hline Household size & 0.048 & 0.138 & 0.725 \\
\hline Farming experience & 0.076 & 0.044 & $0.084^{c}$ \\
\hline Membership & -0.052 & 1.461 & 0.972 \\
\hline Farm size & 0.047 & 0.081 & 0.559 \\
\hline Ln revenue & -0.722 & 0.389 & $0.064^{c}$ \\
\hline Access to extension & -0.123 & 1.361 & 0.928 \\
\hline Annual interest rate & 7.714 & 0.410 & $0.000^{a}$ \\
\hline Sources & 0.791 & 0.526 & 0.133 \\
\hline Distance to the source km & 0.204 & 0.018 & $0.000^{\mathrm{a}}$ \\
\hline Constant & 5.233 & 4.646 & 0.261 \\
\hline /Sigma & 2.717 & 0.144 & \\
\hline \multicolumn{4}{|l|}{ Log likelihood $=-549.5466$} \\
\hline $\operatorname{LRchi}^{2}(17)=672.35$ & & & \\
\hline Prob $>$ chi $^{2}=0.0000$ & & & \\
\hline Pseudo $^{2}=0.3796$ & & & \\
\hline
\end{tabular}

Note: a, b, and c represent significance level at $1 \%, 5 \%$, and $10 \%$, respectively.

Notwithstanding, this finding refutes Akram, Rime, \& Sarno (2008), who found that respondents with relatively higher wages had greater access to credit than their lower counterparts with relatively lower wages. The coefficient of years of experience in rice farming is positive and statistically significant in influencing the amount of credit received. The positive significance of farming experience shows a direct relationship between farming experience and the amount of credit obtained by farmers. This implies that a unit increase in experience of increases the amount of credit obtained by $7.6 \%$. This result is in line with the study of Saqib et al. (2016) who affirmed that farming experience has a significant influence on farm management decisions. Credit received is expected to be negatively dependent on the interest rate, but the results of the analysis indicate a positive relationship. The coefficient of interest rate is positive and statistically significant in influencing the amount of credit received by rice farmers. The result shows that a unit increase in the interest rate will cause a $7 \%$ increase in the amount of credit received by rice farmers.

The result is in line with Olomola \& Gyimah-Brempong (2014), who found a positive relationship between credit demand and the interest rate in loan demand and rationing among small-scale farmers in Nigeria. Also, the coefficient of distance to the credit source is also positive and statistically significant in influencing the amount of credit received. The result shows that a unit increase in the distance of the credit source will lead to $20 \%$ increase in the credit obtained. The coefficient of the location of Osun is negative and statistically significant, indicating that rice farmers in the region are not likely to demand more credit than their counterparts from the other regions. The result shows that being located in Osun State reduces the probability of demanding more loans by $0.7 \%$. This could imply that many farmers are credit averse because they assume they will be denied on the basis of, credit institutions' stringent conditions. Farmers' opinion on the non- 
transparency of credit processing could be another reason for not applying for credit (Olomola \& GyimahBrempong 2014).

\section{Conclusion and Policy Implications}

An improved version of an endogenous switching regression model that accounts for both heterogeneity and sample selection biases was used to investigate the impact of credit demand on rice productivity in Southwestern Nigeria. A Tobit regression model was employed in measuring the level of participation of rice farmers in the credit market. The results of the first stage of the ESRM (probit model) reveal that some farmers' socio-economic characteristic variables, household asset variables, access to service, climate variables, regional variables, and transaction cost variables are important factors influencing the decision to apply for credit. The results of the second stage of the ESRM show that marital status, educational status, farming experience, farm size, and household size are factors affecting rice productivity among the farmers that participate in the credit market. In the same vein, marital status, educational level, and access to climate information are also significant factors influencing rice productivity among non-participants in the credit market. Results of the Tobit model show that the farmers' location, income from rice farming, farming experience, the interest rate, and distance from the source of credit are significant determinants of the amount of credit received.

These findings suggest that facilitating access to credit by farmers is a good strategy to enhance rice farmers' productivity. Access to credit is an important factor in the quest to achieve increased rice productivity. Therefore, to improve the productivity of rice farmers, government and development partners should work together to improve the conditions of access of rice farmers to suitable agricultural credit, including the policy incentives aimed at lowering the cost of borrowing in the Nigerian agricultural sector. It could also be recommended that policies enhancing and strengthening institutional support may also be valuable in improving the productivity of smallholder rice farmers in Nigeria. A necessary addition should be developed to the assistance already being provided under Nigeria Incentive-Based Risk Sharing System for Agricultural Lending (NIRSAL) in the form of loan guarantees and other risk-sharing incentives, such as a regulatory environment that supports the modern contractual obligations that are characteristic of well-functioning agricultural financing. This would not only contribute to the intensification of rice production in Nigeria to meet its increasing rice demand, but also improve rice farmers' productivity and their households' incomes.

\section{References}

Abdallah, A. H. (2016). Agricultural Credit and Technical Efficiency in Ghana: Is There a Nexus? Agricultural Finance Review, 76(2), 309-324.

Afolami, C. A., Obayelu, A. E., Agbonlahor, M. U. \& Lawal-Adebowale, O. A. (2012). Socioeconomic Analysis of Rice Farmers and Effects of Group Formation on Rice Production in Ekiti and Ogun States of SouthWest Nigeria, Journal of Agricultural Science, 4(4), 233-244.

Akpokodje, G., Lançon, F. \& Erenstein, O. (2001). Nigeria's Rice Economy: State of the Art in NISER/WARDA Nigerian Rice Economy Stakeholders Workshop, Ibadan, 8-9.

Akram, Q. F., Rime, D. \& Sarno, L. (2008). Arbitrage in the Foreign Exchange Market: Turning on the Microscope, Journal of International Economics, 76(2), 237-253.

Akinbode, S. 0. (2013). Profiles and determinants of poverty among urban households in South-west Nigeria. American Journal of Economics, 3(6), 322-329.

Alene, A. D. \& Manyong, V. (2007). The Effects of Education on Agricultural Productivity under Traditional and Improved Technology in Northern Nigeria: An Endogenous Switching Regression Analysis, Empirical Economics, 32(1), 141-159.

Amemiya, T. (1979). The estimation of a simultaneous-equation Tobit model. International Economic Review, 169-181.

Amjad, S. \& Hasnu, S. A. F. (2007). Smallholders' Access to Rural Credit: Evidence from Pakistan, The Lahore Journal of Economics, 12(2), 1-25.

Aravindakshan, S., Rossi, F., Amjath-Babu, T. S., Veettil, P. C. \& Krupnik, T. J. (2018). Application of a BiasCorrected Meta-frontier Approach and an Endogenous Switching Regression to Analyze the Technical Efficiency of Conservation Tillage for Wheat in South Asia, Journal of Productivity Analysis, 49(2-3), 153-171. 
Asfaw, S., Mithöfer, D. \& Waibel, H. (2010). What Impact Are EU Supermarket Standards Having on Developing Countries' Export of High-Value Horticultural Products? Evidence from Kenya, Journal of International Food \& Agribusiness Marketing, 22(3-4), 252-276.

Awe, O. (2006). Ban on Rice Importation Depresses Global Trade. Punch 2006, May 20.

Awotide, B. A., Abdoulaye, T., Alene, A. \& Manyong, V. M. (2015). Impact of Access to Credit on Agricultural Productivity: Evidence from Smallholder Cassava Farmers in Nigeria, paper presented at 2015 International Conference of Agricultural Economists, Milan, Italy, August 9-14.

Awotide, B. A., Karimov, A. A. \& Diagne, A. (2016). Agricultural Technology Adoption, Commercialization and Smallholder Rice Farmers' Welfare in Rural Nigeria, Agricultural and Food Economics, 4(1), 1-24.

Amjad, S. \& Hasnu, S. A. F. (2007). Smallholders' Access to Rural Credit: Evidence from Pakistan, The Lahore Journal of Economics, 12(2), 1-25.

Baiyegunhi, L. J. S., Fraser, G. C. G. \& Darroch, M. A. G. (2010). Credit Constraints and Household Welfare in the Eastern Cape Province, South Africa, African Journal of Agricultural Research, 5(16), 2243-2252.

Balogun, O. L. \& Yusuf, S. A. (2011). Determinants of Demand for Micro Credit among the Rural Households in South-Western States, Nigeria, Journal of Agriculture and Social Science, (7), 41 - 48.

Benin, S., Smale, M., Pender, J., Gebremedhin, B. \& Ehui, S. (2004). The Economic Determinants of Cereal Crop Diversity on Farms in the Ethiopian Highlands, Agricultural Economics, 31(2-3), 197-208.

Binam, J. N., Gockowski, J. \& Nkamleu, G. B. (2008). Technical efficiency and productivity potential of cocoa farmers in West African countries. The Developing Economies, 46(3), 242-263.

Chandio, A. A., Magsi, H., Rehman, A. \& Sahito, J. G. M. (2017). Types, Sources and Importance of Agricultural Credits in Pakistan, Journal of Applied Environmental and Biological Sciences, 7(3), 144-149.

Cochran, W. G. (1977). Sampling techniques, 72-74.

Danso-Abbeam, G. \& Baiyegunhi, L. J. S. (2017). Adoption of Agrochemical Management Practices among Smallholder Cocoa Farmers in Ghana, African Journal of Science, Technology, Innovation and Development, 9(6), 717-728.

De, N. N., Uchiyama, T. \& Ohara, K. (2005). Vietnam Agricultural Extension: Its Roles, Problems and Opportunities, Bulletin of the Faculty of Bio resources-Mie University (Japan).

Diagne, A. \& Zeller, M. (2001). Access to Credit and Its Impact on Welfare in Malawi, Research Report 116, Washington, DC: International Food Policy Research Institute.

Enete, A. A. \& Igbokwe, E. M. (2009). Cassava Market Participation Decisions of Producing Households in Africa, Tropicultura, 27(3), 129-136.

Feder, G., Lau, L. J., Lin, J. Y. \& Xiaopeng, L. (1989). Agricultural Credit and Farm Performance in China, Journal of Comparative Economics, 13(4), 508-526.

Freeman, A. \& Durden, S. L. (1998). A three-component scattering model for polarimetric SAR data. IEEE Transactions on Geoscience and Remote Sensing, 36(3), 963-973.

Fuglie, K. O. \& Bosch, D. J. (1995). Economic and Environmental Implications of Soil Nitrogen Testing: A Switching-Regression Analysis, American Journal of Agricultural Economics, 77(4), 891-900.

Greene, W. H. (2003). Econometric analysis. Pearson Education India.

Guirkinger, C. \& Boucher, S. R. (2008). Credit constraints and productivity in Peruvian agriculture. Agricultural Economics, 39(3), 295-308.

Gyinadu, A., Bakang, J. E. A. \& Osei, C. K. (2015). Determinants of adoption of yam minisett technology in Ghana: A case study of yam farmers in the Kintampo north district of Ghana. Journal of Agricultural Economics, Extension and Rural Development, 3(7), 293-302.

Hausman, J. A. (1978). Specification tests in econometrics. Econometrica: Journal of the Econometric Society, $1251-1271$.

Hausman, J. A. (1983). Specification and Estimation of Simultaneous Equation Models, Chapter 7 in Handbook of Econometrics, (1), 391-448.

Heckman, J. J. (1979). Sample Selection Bias as a Specification Error, Econometrica, (47), 153-161.

Hitayezu, P., Okello, J. J. \& Gor, C. O. (2010). Drivers of Household Participation in the Rural Non-Farm Labor Markets in the Post-War Rwanda (No. 320-2016-10088).

Iqbal, M., Ahmad, M. \& Abbas, K. (2003). The Impact of Institutional Credit on Agricultural Production in Pakistan, The Pakistan Development Review, 42(4), 469-485.

Karlan, D. S. \& Zinman, J. (2008). Credit Elasticities in Less-Developed Economies: Implications for Microfinance, American Economic Review, 98(3), 1040-68. 
Kandlikar, M. \& Risbey, J. (2000). Agricultural Impacts of Climate Change: If Adaptation Is the Answer, What Is the Question? Climatic Change, 45(3-4), 529-539.

Kassie, M., Teklewold, H., Jaleta, M., Marenya, P. \& Erenstein, O. (2015). Understanding the Adoption of a Portfolio of Sustainable Intensification Practices in Eastern and Southern Africa, Land Use Policy, (42), 400-411.

Kumar, C. S., Turvey, C. G. \& Kropp, J. D. (2013). The Impact of Credit Constraints on Farm Households: Survey Results from India and China, Applied Economic Perspectives and Policy, 35(3), 508-527.

Lee, L. F. (1978). Unionism and Wage Rates: A Simultaneous Equations Model with Qualitative and Limited Dependent Variables, International Economic Review, 19(2), 415-433.

Lokshin, M. \& Sajaia, Z. (2004). Maximum Likelihood Estimation of Endogenous Switching Regression Models, The Stata Journal, 4(3), 282-289.

Luan, D. X. \& Bauer, S. (2016). Does Credit Access Affect Household Income Homogeneously across Different Groups of Credit Recipients? Evidence from Rural Vietnam, Journal of Rural Studies, (47), 186-203.

Maddala, G. S. \& Nelson, F. D. (1975). Switching Regression Models with Exogenous and Endogenous Switching, in Proceedings of the American Statistical Association, Business and Economics Section, (5), 423-426.

Maddala, G. S. (1983). Limited-Dependent and Qualitative Variables in Econometrics, No. 3. Cambridge: Cambridge University Press.

McDonald, J. F. \& Moffitt, R. A. (1980). The Uses of Tobit Analysis, The Review of Economics and Statistics, 6(2), 318-321.

Mishra, A. K., El-Osta, H. S., Morehart, M. J., Johnson, J. D. \& Hopkins, J. W. (2002). Income, wealth, and the economic well-being of farm households (No. 1473-2016-120697) USDA.

Mmbando, F. E. \& Baiyegunhi, L. J. (2016). Socio-Economic and Institutional Factors Influencing Adoption of Improved Maize Varieties in Hai District, Tanzania, Journal of Human Ecology, 53(1), 49-56.

Nouman, M., Siddiqi, M. F., Asim, S. M. \& Hussain, Z. (2013). Impact of Socio-economic Characteristics of Farmers on Access to Agricultural Credit, Sarhad Journal of Agriculture, 29(3), 469-476.

Nnadi, F. N. \& Akwiwu, C. D. (2008). Determinants of youths' participation in rural agriculture in Imo State, Nigeria. Journal of Applied Sciences, 8(2), 328-333.

Nyangena, W. \& Köhlin, G. (2008). Estimating Returns to Soil and Water Conservation Investments: An Application to Crop Yield in Kenya, Environment for Development Discussion Paper Series, EfD DP 0832.

Obih, U. \& Baiyegunhi, L. J. (2017). A review of factors influencing domestic demand-supply gap and high import bills for rice in Nigeria: implications for development of rice sector. Africa growth Agenda, 2017(Jul/Sep 2017), 18-21.

Okorie, F. C., Okeke, I., Nnaji, A., Chibo, C. \& Pat-Mbano, E. (2012). Evidence of Climate Variability in Imo State of Southeastern Nigeria, Journal of Earth Science and Engineering, 2(9), 544-553.

Olomola, A. \& Gyimah-Brempong, K. (2014). Loan Demand and Rationing among Small Scale Farmers in Nigeria. Discussion Paper Series 01403. Washington, DC: International Food Policy Research Institute (IFPRI).

Onumah, J. A., Al-Hassan, R. M. \& Onumah, E. E. (2013). Productivity and technical efficiency of cocoa production in Eastern Ghana. Journal of Economics and Sustainable Development, 4(4), 106-117.

Pal, D. \& Laha, A. K. (2015). Sectoral Credit Choice in Rural India, Journal of Choice Modelling, (14), 1-16.

Perloff, J. M., Lynch, L. \& Gabbard, S. M. (1998). Migration of seasonal agricultural workers. American Journal of Agricultural Economics, 80(1), 154-164.

Rahman, S. (2009). Whether Crop Diversification is a Desired Strategy for Agricultural Growth in Bangladesh? Food Policy, 34(4), 340-349.

Rejitis, A. N., Tsiboukas, K. \& Tsoukalas, S. (2002). Measuring technical efficiency in the Greek agricultural sector. Applied Economics, 34(11), 1345-1357.

Saboor, A., Hussain, M. \& Munir, M. (2009). Impact of Micro Credit in Alleviating Poverty: An Insight from Rural Rawalpindi, Pakistan, Pakistan Journal of Life and Social Sciences, 7(1), 90-97.

Saqib, S. E., Kuwornu, J. K. M., Panezia, S. \& Ali, U. (2017). Factors Determining Subsistence Farmers' Access to Agricultural Credit in Flood-Prone Areas of Pakistan, Kasetsart Journal of Social Sciences, (30), 1-7.

Saqib, S., Ahmad, M. M., Panezai, S. \& Ali, U. (2016). Factors Influencing Farmers' Adoption of Agricultural Credit as a Risk Management Strategy: The Case of Pakistan, International Journal of Disaster Risk Reduction, (17), 67-76. 


\section{Journal of Economics and Behavioral Studies (ISSN: 2220-6140)}

Vol. 11, No. 1, pp. 166-180, February 2019

Sebopetji, T. O. \& Belete, A. (2009). An Application of Probit Analysis to Factors Affecting Small-Scale Farmers' Decision to Take Credit: A Case Study of the Greater Letaba Local Municipality in South Africa, African Journal of Agricultural Research, 4(8), 718-723.

Shalmani, A. F., Rabbi, R., Ahamad, S., Ali, S., Chandio, A. S., Ahmad, W., Ilyas, A. \& Din, I. U. (2017). Determinants of Commercialization and Its Impact on the Welfare of Smallholder Rice Farmers by Using Heckman's Two-Stage Approach, Journal of the Saudi Society of Agricultural Sciences. Article in press.

Siddiqi, M. N. (2004). Riba, bank interest and the rationale of its prohibition. Jeddah, Saudi Arabia: Islamic Research and Training Institute.

Tijani, A. A., Alimi, T. \& Adesiyan, A. T. (2006). Profit Efficiency among Nigerian Poultry Egg Farmers: A Case Study of Aiyedoto Farm Settlement, Nigeria, Research Journal of Agricultural Biological Sciences, 2(6), 256-261.

Tesfahunegn, G. B., Mekonen, K. \& Tekle, A. (2016). Farmers' perception on causes, indicators and determinants of climate change in northern Ethiopia: implication for developing adaptation strategies. Applied Geography, (73), 1-12.

Tiwasing, W., Tiwasing, P. \& Hapeshi, K. (2018). Graphic Design for Local Agricultural Products: A Case Study of Thai Jasmine Rice Leaf Drink "ThaiSuwan” Brand, Roi Et Province, Thailand. In Research for 22nd International Conference. Newcastle University.

Tobin, J. (1958). Estimation of relationships for limited dependent variables. Econometrica: Journal of the Econometric Society, 24-36.

USDA. (2016). United States Department of Agriculture (USDA). Global Agricultural Information Network (GAIN) report. USDA Foreign Agricultural Services (FAS), April 2016.

Yehuala, S. (2008). Determinants of Smallholder Farmers Access to Formal Credit: The Case of Metema Woreda, North Gondar, Ethiopia, M.Sc. Thesis, Haramaya University. 